\title{
3. Capitalism and the curse of external effects
}

\section{Claude Henry}

Every child worldwide now faces existential threats from climate change and commercial pressures. (WHO, UNICEF and The Lancet, 2020)

I have found, in business in particular but also in politics, that when something is in your personal best interests, the ability of the mind to rationalize that that's the right thing is really quite extraordinary. I have seen it in others, and I have seen it in myself.

(Senator Mitt Romney at President Trump's impeachment trial)

The most celebrated pronouncement in economics - Adam Smith's on the "invisible hand": "By pursuing his own interest he frequently promotes that of society more effectually than when he really intends to promote it" (Smith, 1776) - today looks as outdated as the Commandment: "Thou shalt not bear false witness" (Matthew 19:16-19).

Instead of a competitive market, where providers meet consumers' demands, we have at the core of the economy a nexus of dominant firms, the activities of which bring more harm than good: abusers deeply indifferent to the welfare of the people, particularly of their health and the environment in which they live, rather than providers of goods and services meeting their needs. To maintain their dominance, they cover up the harmful effects of their activities, they manipulate the relevant information - scientific knowledge in particular. In democracies they marshal their outsized wealth and power to subvert representative and administrative institutions, the legitimacy of which they hollow out, hence still increasing their domination. In authoritarian regimes, under various forms of state or crony capitalism, firms and public authorities are tightly interwoven; only to the extent they deem it necessary to "keep them happy" - that is, quiet - do they worry about ordinary people.

In "market capitalism", it's not market, it's capitalism as it functions today that is the culprit (see, for instance, Philippon, 2019a, 2019b). ${ }^{1}$ Even worse are the Chinese version, the defunct Soviet one, and various forms of crony capitalism in developing countries. Mark Twain once said, when reporting about the "water wars" along the Colorado River: "Whiskey is for drinking, water is for fighting about". In this chapter we illustrate - mainly with references to natural capital, climate in particular, and to public health - another dichot- 
omy: Smith's market is for making production and exchange more efficient; contemporary capitalism is for looting, duping and dominating. Economists' famed "external effects" are pervading and corrupting the whole organism, they are feeding the exorbitant financial returns expected by shareholders, or by any sort of people in control. In every possible way, capitalism as it now functions is destroying life on Earth. As Robert Watson, former chair of the Intergovernmental Panel on Climate Change (IPCC) (1997-2002) and later on of the Intergovernmental Science-Policy Platform on Biodiversity and Ecosystem Services (IPBES) (2016-20), puts it:

The continued loss of biodiversity is not only an environmental issue. It risks undermining the achievement of most of the UN Sustainable Development Goals. It is central to development, through food, water and energy security. It has significant economic value, which should be recognised in national accounting systems. It is a security issue as far as loss of natural resources, especially in developing countries, can lead to conflict. It is an ethical issue because loss of biodiversity hurts the poorest people, further exacerbating an already inequitable world. And it is also a moral issue, because we should not destroy the living planet. Why has that loss been ignored? (Watson, 2019)

Hereafter are elements of an answer.

\section{CAPITALISM OF LOOTING}

"Climate change is the result of the greatest market failure the world has ever seen" (Stern, 2007). Or equivalently: the ultimate external effect. External indeed in the sense of bypassed, deliberately.

Firms producing fossil fuels control proven reserves, the burning of which would generate about $2500-3000 \mathrm{Gt}$ of $\mathrm{CO}_{2}$ emissions - that is, more than four times the amount beyond which the increase in the Earth's mean temperature would exceed $1.5^{\circ} \mathrm{C}$ (IPCC, 2018). Warming could then "activate important tipping elements, raising the temperature further to activate other tipping elements in a domino-like cascade that could take the Earth System to even higher temperatures" (Steffen et al., 2018, p. 8254). Elementary precaution thus requires that the level of these reserves be frozen. It is not, it is expanding, and it is expanding at an accelerating pace.

The fire power of the five largest stock market-listed oil and gas companies is impressive. Their profits in 2018 (for them a rather good albeit not exceptional year) are respectively, according to Moody's Investors Service, \$23 billion for Royal Dutch Shell, \$21 billion for ExxonMobil, \$18 billion for Chevron, $\$ 14$ billion for Total and $\$ 13$ billion for BP. It is thus quite easy for them to spend $\$ 200$ million a year in covert lobbying operations meant to delay, skew, block policies aimed at mitigating climate change. They spend about the 
same amount, with great fanfare, on branding campaigns, suggesting they are diligently taking part in the fight against climate change (Collins, 2019). On April 8, 2019, Shell made an additional move, announcing a significant expansion of its greenwashing operations: $\$ 100$ million will be allocated each year to investments "in natural ecosystems as part of a strategy to act on climate change" (Monbiot, 2019). ExxonMobil is a pillar of Stanford's Global Climate and Energy Project. The late David Koch (see the "Capitalism of Influence and Dominance" section below) was a Life Member of the MIT Board. In 2019, at last, BP's fake humanism was pushed back by the Royal Shakespeare Company's decision to dispense with its donations. Financially these actions absorb only a tiny fraction of the resources that the companies muster; they are obviously not jeopardizing exploration and production projects. Nevertheless, they provide enough ammunition to successfully manipulate politicians, regulators and media, and to deceive the general public. Blowing smoke screens in these ways, it must be acknowledged, is, however, a far cry from stripping university charters of the right to free thinking, a recent Chinese move extending totalitarianism that "not only forbids you to express - even to think - certain thoughts, but dictates what you shall think" (Orwell, 1941; original emphasis). It is nevertheless an unwelcome, to say the least, contribution to the confusion that impedes the confrontation of looming environmental catastrophes.

With profits in 2018 amounting to $\$ 110$ billion, Saudi Aramco is in a class of its own. Moody's doesn't provide equally reliable figures for the Chinese, Russian, and other, state-controlled companies; however, the size of their contributions to public budgets is a good indicator of their strength. Altogether - and also including coal companies, especially those active in Asia - since the December 2015 climate agreement approved in Paris, they have massively increased already massive investments in exploration and extraction of fossil fuels. Financing these ventures has not been a problem, as they could rely not only on their profits, but also on unflinching public subsidies and on loans they are among the main beneficiaries of the prevailing ultra-low interest rates - and participations from global banks, amounting to more than $\$ 1$ trillion (BankTrack et al., 2019), not including another $\$ 500$ billion (about 40 percent from Chinese banks) to coal projects.

Bribing disbursements are mere slivers from these enormous amounts. They are nevertheless of strategic importance for the companies: they are control levers on corrupt governments along the processes of negotiating and implementing highly profitable exploration and extraction contracts. Referring to the government of Equatorial Guinea, among the most corrupt ones, Rachel Maddow (2019, p. 356) writes: "So long as nasty, authoritarian strongmen like Teodoro Obiang didn't start making untoward new demands on oil and gas producers, and they honored ExxonMobil's bottom line imperatives - the 'sanctity of contract' - all was cool'. 
Teodoro Obiang Nguema Mbasogo has been President of the Republic of Equatorial Guinea since 1979, regularly re-elected with more than 90 percent of the votes. He has avoided "untoward new demands" above the $\$ 25$ billion that the oil and gas companies - mainly Marathon Oil, Noble Energy and in a dominant position ExxonMobil - have been channeling since 2019 towards him and members of his family and of his clique, without jeopardizing the profitability of their investments. During this decade, ordinary Guineans (about 1.4 million in 2020) got even poorer than they were before the oil era, with less access to drinking water, to health services and to education, and suffering from worsening malnutrition and infant mortality.

The situation in Equatorial Guinea appears as an extreme case of the resource curse; it is, for example, rare for a strongman to be accused by the UN Commission of Human Rights of directly overseeing torture of opponents. Nevertheless, it is a manifestation of a general pattern: for oil companies operating in developing countries it is optimal, as far as the smoothness of their operations and the size of their profits are concerned, to concentrate financial transfers on corrupt minorities that firmly control their respective countries; in this respect, countries like Angola, Guyana, Kazakhstan, Nigeria, Peru, along with Equatorial Guinea, proved particularly "cool". It is a key component of oil companies' business model; hence the furious reactions against Section 1504 of the Dodd-Frank Act.

After the Act - meant to reform regulation of the US financial sector, and of some other business practices - was passed by Congress in 2010, US oil companies led by the American Petroleum Institute and by ExxonMobil, respectively their professional association and their natural leader, started a guerrilla war to obstruct the implementation of Section 1504 of the Act, which:

requires the SEC (Securities and Exchange Commission) to issue final rules that require each resource extraction issuer to include in an annual report...information relating to any payment made by the resource extraction issuer, a subsidiary of the resource extraction issuer, or an entity under its control, to a foreign government... for the purpose of the commercial development of oil, natural gas, or minerals... Foreign government means a foreign government, a department, agency, or instrumentality of a foreign government, or a company owned by a foreign government. (SEC, n.d.)

For six years companies succeeded in keeping Section 1504 in limbo, by making the most of the opportunities for appeal that the US judicial system offers. Then came Donald Trump and a Republican-dominated Senate; together they wasted no time in killing Section 1504. The main Senate executor has been James Inhofe, Republican of Oklahoma, also known as a vociferous denier of climate science - a coherent scenario. 


\section{BOX 3.1 BASKING IN OIL}

We are about to take another major step in the development of promising oil and gas fields in the Arctic. (Vladimir Putin, inauguration of the first Rosneft-ExxonMobil drilling platform in the Kara Sea, Sochi, August 9, 2014; Maddow, 2019, p. 269)

In April 2019, we announced a significant discovery at the Blacktip prospect in the Perdido Corridor within the deep-water US Gulf of Mexico. This and other drilling successes in the US Gulf of Mexico highlight the potential of this area. (Shell, 2019)

We are very pleased with this first significant oil discovery made just after our entry into Block 58 offshore Surinam. (Kevin McLachlan, Senior Vice-President of Exploration, Paris, January 7, 2020; see Total, 2020)

Chevron has upped its Permian Basin (Texas) resource estimate to more than 21 billion barrels of oil equivalent, more than double the company's estimate just three years ago (Jay Johnson, Executive Vice-President of Exploration and Production at Chevron, Annual Security Analyst Meeting, New York, March 3, 2020; see Spencer and Greenhalgh, 2020).

Either all that oil cited in Box 3.1 remains in the ground, and the prospect is a broad financial crisis, or it is extracted and burnt, which amounts to a crime against humanity.

The race is accelerating, closer and closer to a cliff. Will a jump over a financial cliff - that is, the crisis contemplated by Governor of the Bank of England, Mark Carney, when it becomes clear that the reserves, on which the companies' high market valuations are based, are mere stranded assets, an enormous financial bubble will burst (see the Part VI of this book: "Investors") - derail the race before a fatal climate tipping point is reached?

The firms' hypocrisy about these prospects matches their unflinching exclusive quest for profit and growth. Ben van Beurden, CEO of Shell, has set a new standard in hypocrisy. In his remarks to the October 2018 Oil \& Money Conference, he said: "Shell's core business is and will be for the foreseeable future very much in oil and gas". What is required to keep global warming under $1.5^{\circ} \mathrm{C}$ "can be done in massive reforestation. Think of another Brazil in terms of rainforest" (Redd-Monitor, 2019). Is it possible that he was not aware that the real Brazil is controlled by people for whom the Amazon forest is a nuisance, an obstacle against development as they see it - that is, agrobusiness, logging and mining activities, involving Brazilian and foreign firms like McDonald's, Burger King, KFC, AngloAmerican, Mineraçao Rio do Norte, Norsk Hydro, Rio Tinto, Vale and so on? Mining companies are no less brutal than fossil-fuel ones, killing large numbers of people in accidents that could 
and should have been avoided, and routinely having scores of indigenous activists murdered and, as the case may be, supporting lawyers and journalists as well (Souter et al., 2017). Jair Bolsonaro, president of Brazil since January 1,2019 , hates the indigenous inhabitants of the forest even more than he hates the trees; he sees them as Untermenschen ${ }^{3}$ who, as he once said, "smell, are undereducated and don't speak our language" (see in Part V, "Entrepreneurs", Chapter 44 of this book, the story of some of these so-called Untermenschen). He thinks the Holocaust can be forgiven, as he said at a meeting with evangelical leaders on April 13, 2019. He thus might also think that he would be forgiven for transposing into the Amazon forest Hitler's Endlösung der Judenfrage ${ }^{4}$ Capitalism is not averse to that kind of playmate.

As far as coal is concerned, public and private Chinese institutions run the show, in ways that are, to say the least, beneficial neither to the climate nor to the countries where they operate. As Mohamed Adow, Christian Aid's head of climate policy for Africa, puts it: "It is deeply unfair for China to get Africa hooked on fossil fuels and debt when it comes to building Africa's infrastructure, while China is starting to adopt clean, cheap technologies of the $21 \mathrm{st}$ century" (Watts, 2019).

Indeed, while China is lessening its dependence on coal - mainly aiming at alleviating the pollution of air and water within the country - engineering firms and banks, mostly state-owned, are making up for lost business at home by frantically expanding into other countries, partly under the umbrella of the Belt and Road Initiative. More than $100 \mathrm{GW}$ of coal-fired capacity of electricity production have recently been completed or are under development in 23 countries. During the 2000-09 decade, state banks have provided loans and participations for a total amount of $\$ 49$ billion (Global Development Policy Center, 2020). An emblematic case is the $600 \mathrm{MW}$ power plant inaugurated in April 2019 at Tharparkar, Sindh Province, Pakistan. A nearby opencast mine has been established to provide coal - low grade and severely polluting - in a country where miners are exposed to working conditions among the harshest worldwide. The choice is all the more significant as there are in the same province favorable wind corridors as well as abundant sunshine.

Far away from Africa and South Asia, powerful political and economic Chinese actors are pushing, along with Russian and US counterparts, ${ }^{5}$ for the transformation of the Arctic region from a natural asset, the protection of which is essential to the balance of the planet, into a pool of non-renewable resources to be systematically tapped, in particular those very fossil fuels whose use must on the contrary be drastically scaled down. The Chinese approach amounts to doubling down on transforming the Arctic from a shield into a relentless engine of climate change, with huge quantities of methane ready to be released from melting permafrost, in excess of the soaring quantities of methane that the fossil-fuel industry worldwide routinely leaks or intentionally releases in the 
atmosphere. The atmospheric concentration of methane, which is a far more potent GHG than $\mathrm{CO}_{2}$ - by a factor 72 over 20 years and 21 over 100 years, this difference resulting from the fact that $\mathrm{CO}_{2}$ remains for far longer periods in the atmosphere - has already doubled since the beginning of the Industrial Revolution (Hmiel, 2020).

Climate is not the sole victim of fossil-fuel-based capitalism. From extraction to end uses, fossil fuels are leaving trails of destruction. Oil has devastated - polluting and poisoning water and soil beyond repair - the Niger delta and the Ecuadorian Amazon forest, a number of coastal settlements and ecosystems, and has destroyed large tracts of the Alberta boreal forest and vital ecosystems on the Xing Kiang plateau. Damage from coal is even broader. Assessing the situation in India, Mayuri Chabukdhara (2019, p. 87) writes: "Environmental challenges [due to coal] include large scale landscape damage, soil erosion, loss of forest ecosystem and wildlife habitat, air, water and soil pollution". This is not specific to India; worldwide, coal has destroyed lives and natural capital on par with world wars.

In tropical rainforests, not only in the Amazon basin, capitalism is leaving other trails of looting and destruction. In Asia, tropical forests also fare badly; capitalism, making the most of public authorities' weaknesses, is again the engine. These forests extend from India to Malaysia, Indonesia and Papua New Guinea. They are exploited and burnt - generating thick air pollution in Southeast Asia and bringing black carbon to the Eastern Himalaya mountains, hence accelerating the melting of the glaciers - to the point that their very existence is in balance. In most places public authorities are no match - often being bribed - for international logging and paper mills companies selling the products in China, Japan, India, and so on; nor for agribusinesses converting natural forests into palm oil plantations to meet the increasing demands of food companies for their popular brands all over the world. In Indonesia and Malaysia, there are projects for producing and selling more "green" diesel, from more palm oil, hence more deforestation. The ultimate culprits are the American, Asian and European companies involved, and their customers, along with the numerous banks that finance the destructive activities. "Forest \& Finance", a report from the community group TuK Indonesia and the Dutch consultancy Profundo (Forests \& Finance, n.d.; see also Rainforest Action Network [RAN], 2020), shows that financial institutions (mainly China Development Bank, HSBC, JPMorgan, Mizuho Financial, and three Indonesian banks) provided more than $\$ 38$ billion worth of commercial loans and underwriting facilities to 50 companies implicated in deforestation in the Asia-Pacific region, from 2010 to 2015, in four sectors: palm oil, pulp, rubber and tropical timber. If the present trends are maintained - and there are not many credible counterweights - most of the Southeast Asia rainforests will be 
gone by mid-century, and with them a rich and original biodiversity as well as the carbon stored in trees and in soil.

Most frightening: the reservoirs of, mainly unknown, pathogens previously kept away in the depths of the forests will be exposed. As Wilcox and Ellis (2006, p. 12) observed some time ago: "Today, both deforestation and emerging infectious diseases remain largely associated with tropical regions but have impacts that extend globally". And not all these new diseases will be as restrained as COVID-19: they will kill children no less than adults. The most frequent mediators between emerging pathogens and humans are wild animals that have been disturbed by human actions. It is shown in Kreuder-Johnson et al. (2020) that it is the very actions that threaten wildlife species' survival first of all ecosystem destruction and all modes of consuming animal bodies, or in many instances just parts of them - that also enable the transmission of viruses from animals to humans. ${ }^{6}$

The threats to boreal forests are no doubt less pressing. Nevertheless, they are more serious than generally recognized. In Canadian boreal forests, logging companies are operating in ways that are not up to the country's pretense to care for nature and the environment. The rate of deforestation is far higher than officially acknowledged. And, viciously, after a zone has been exploited, massive scars (all sorts of infrastructure built for the logging operations) are left over; they make regenerations of the trees all the more difficult (Wildlands League, 2019).

South Atlantic waters fronting the western coast of Africa offer a striking example of pillage of natural capital by powerful foreign firms, mainly from Asia. They send fleets of fishing ships equipped with the most efficient catching devices. Among these ships are those of the state-owned China National Fisheries Corporation, the exactions of which - notably robbing the livelihood of traditional African fishers - are not in tune with the spirit of cooperation that China pretends to display in Africa. They recently outsourced practices not uncommon inside China: abduction of those who stand in the way. An example: Ghana has appointed observers on fishing vessels whose mission is to detect violations of fisheries law; some have disappeared from the country. Africans are not the sole victims of Chinese fishing companies. Under the protection of armed Chinese Coast Guard vessels, they plunder parts of the Indonesian exclusive economic zone in the South China Sea. Chinese powerful trawlers not only take the fish, they destroy essential life-supporting ecosystems by scraping the bottom of the sea. The Indonesian central government shies away from confronting China, close neighbor and largest trading partner.

The seabed is also under threat. In 2001, Russia made the first claim of sovereignty on a portion of seabed, specifically on a portion of the Arctic seabed. Since then, 83 countries followed suit, making claims on a total of 37 million $\mathrm{km}^{2}$. However, it is in the vast extent of ocean under international jurisdiction 
that the richest prizes of rare earths, metal nodules and other valuable minerals are to be found. The UN International Seabed Authority (ISA) is in charge of regulating the mining activities soon to be launched; later this year (2020), ISA intends to publish a Mining Code as a reference for regulation. Several companies - in particular, Canadian, Chinese and German ones - are already licensed and ready to start operations as soon as the Code is published, with scant concern for so-called external effects: "mining licenses [have been] granted prior to a consensus on how to mitigate environmental impacts of mining", due to which all flora and fauna living in the ocean depths will suffer (Jouffray et al., 2020, p. 48). This is not well known, which doesn't mean it isn't of great significance: "The deep sea is a vast, pristine and largely unexplored area, with rich biodiversity and biophysical systems which are as diverse and dynamic as terrestrial ones, but far more expansive. These systems support key processes in carbon sequestration which in turn affect global carbon cycles and climate regulation" (Howard et al., 2020, p. 4).

Limited experiments on the seabed suggest what those impacts might be. They are described as follows in a paper published in Nature: "As the collectors move across the sea floor, they would stir up large clouds of soft sediment that would disperse, possibly for thousands of kilometres, before eventually resettling. At high densities, sediment plumes can bury and smother animals on the sea floor... Once the nodules have been collected, they'll be shunted up a kilometres-long tube to a large surface support vessel which will sort out millions of nodules a day and return the waste sediments to the sea, creating yet another plume" (Hefferman, 2019, p. 468). Having devastated the upper layers of the oceans, capitalism is now aiming at the depths.

\section{CAPITALISM OF DECEIT}

In Akerlof's (1970) seminal model that illustrates the consequences of information asymmetry on the functioning of markets, the largest profit is made by sellers of "lemons" (i.e., bad used cars) when lemons and "peaches" (i.e., good used cars) cannot be distinguished on the market, provided the latter has not collapsed. Similarly, as political scientists Noemi Oreskes and Erik Conway (2010) put it in the introduction to their book Merchants of Doubt, which is the classical reference on the subject: "Call it the Tobacco Strategy. Its target was science, and so it relied heavily on scientists - with guidance from industry lawyers and public relations experts - willing to hold the rifle and pull the trigger" (p. 6).

In the 1950s and 1960s, more and more epidemiological studies were produced that documented the health hazards associated with smoking. The American producers of tobacco, American Tobacco, Benson \& Hedges, Philip Morris, R.J. Reynolds, US Tobacco, and so on, organized a powerful counter- 
offensive through a common organism called the Tobacco Industry Research Committee. The Committee's task was to sponsor and promote research focusing on the imperfections of the epidemiological studies - exaggerating them when deemed expedient - and on possible alternative origins for the health hazards associated with smoking. A seemingly scientific institution was created to plan and coordinate this defensive research. Its links with the tobacco industry remained concealed from the public, and its name projected a highly respected image: the Alexis de Tocqueville Institution (François de la Rochefoucauld (1664 [2012], No. 218) would see here another "hommage du vice à la vertu" "). Professor Fred Seitz, a scientist with an impressive résumé (distinguished solid state physicist, president for seven years of the National Academy of Sciences, then for ten years of the Rockefeller University, from which he retired in 1979), was in 1976 put in charge of the research program financed by the tobacco industry at the Alexis de Tocqueville Institution. They sponsored both good cars (for example, Stanley Prusiner's research on the pathogenic action of mutated prions in the brain) and bad cars (spurious statistical studies to put in doubt the validity of epidemiological studies); such a mix reinforced the credibility of the operation. A lot of disguised bad cars were sold, and it lasted a long time. The first condemnation of tobacco firms at national level came as late as 2006; based on the Racketeer Influenced and Corrupt Organization Act, it was indeed infamous, but it didn't erase half a century of deceit and exceptional profits on the back of millions of avoidable individual tragedies.

The main instruments and methods designed for the defense of the tobacco industry have been adapted to the conduct of what became known as "climate wars" (see Michael Mann's account in Chapter 60 in Part VII: "Communicators"). In particular, the logistics are structured along the same lines, articulating the following actors:

- Behind the scene, powerful firms (directly or through industry associations) motivated by strong industrial and financial interests. They are more diversified than in the tobacco case, and include ExxonMobil, BP, Shell, Peabody, the National Mining Association, Ford, General Motors, Koch Industries, and so on.

- On the scene, fake scientific institutions, established from scratch and financed by the above firms. They have multiplied, always with names that make them look respectable: American Council on Science and Health, Friends of Science, Greening Earth Society, Natural Resources Stewardship Project, the Advancement of Sound Science Coalition, and so on.

- Scientists, and others, organized and supported within these institutions. First the old guard from tobacco, still eager to fight and to bask in the 
limelight of the TV talk shows; despite having their scientifically productive life well behind them, they cannot bow out. Then newcomers like meteorologist Richard Lindzen (a member of the National Academy of Sciences) and astrophysicist Sallie Baliunas (highly regarded for her scientific achievements, then spreading the good word that the real culprit for climate change is the sun). All these are scientists, but they are joined by people who are essentially lobbyists, media operators and manipulators. The most prominent are Mark Moreno (who also coordinated the operation "Swift Boat Veterans for Truth" that successfully put in doubt John Kerry's record in Vietnam), Steven Malloy (known as "junk science" commentator on Murdoch's Fox News Channel), and Frank Luntz (Republican pollster whose "Straight talk memo" played a remarkable role in the 2004 electoral campaign). ${ }^{8}$ On the contrary, scientists working inside companies like Exxon and Peabody, who were aware of serious risks associated with climate change, have been silenced; these companies are now charged with misrepresenting the issues to stockholders and regulators. In 1981, an internal Exxon memo, later on revealed in a lawsuit process, warns that "it is distinctly possible that $\mathrm{CO} 2$ emissions from the company's 50-year plan will later produce effects which will indeed be catastrophic, at least for a substantial fraction of the earth population".

Elaborate methods have been tested and refined, reminiscent of Plato's Gorgias: "Socrates: You are saying, Gorgias, that the rhetorician will have greater powers of persuasion than the physician even in a matter of health". Indeed, these methods make the most of:

- Common sense: "How can you tell me that they have any idea what climate is going to be like 100 years from now if they can't tell me what the weather is going to be like in four months, or even next week?" (Timothy Ball, from Friends of Science, interviewed on August 12, 2006, by a journalist of the Toronto Globe and Mail; see Montgomery, 2006).

- Doggedness: "They promoted claims that had already been refuted in the scientific literature, and the media became complicit as they reported these claims as if they were parts of an ongoing scientific debate" (critique formulated by Oreskes and Conway, 2010, p. 241).

- Unequal rules: "Because scientists are so quick to acknowledge when something is not exactly correct, the attackers have won many apologies, corrections or reinterpretations, which they have used to argue that all of climate science is frail and uncertain" (Hoggan, 2009, p. 131).

- Balance: "It seems to demand that journalists present competing points of view on a scientific question as though they have equal scientific weight, when actually they do not" (Boykoff and Boykoff, 2003, p. 127). This is 
particularly pernicious: a scientific result becomes a mere opinion, to be debated against a different opinion.

The sponsors' investments paid off. According to the Pew Research Center: in 2006, 79 percent of the Americans thought that "there is solid evidence the Earth is warming" and 50 percent that it was "because of human activity". In 2010 , the corresponding figures were respectively 53 percent and 34 percent. Since then, recuperation has been slow, hindered by entrenched prejudices. In Book 2 of Virgil's Aeneid, Aeneas tells Queen Dido the story of Troy's last days: "Blind with frenzy, we site the accursed creature on top of our sacred citadel. Then Cassandra, who, by the god's decree, is never to be believed by Trojans, reveals our future fate by her lips". In America, Apollo's decree has morphed into ExxonMobil's (and the like) decree.

The chemical industry has been, for decades, no less successful in persuading, indeed duping, farmers, experts, politicians and the general public, that only industrial agriculture based on their products is able to ensure worldwide food security, and that this unique performance is worth a few inconveniences, despite evidence pointing otherwise (see IPCC, 2019; IPBES, 2019 and Chapter 61 by David Montgomery in Part VII: "Communicators").

Bending the truth by all possible means has been a constant strategy of the firms producing pesticides, while the tragedy was swelling, of insect and bird disappearance from entire regions dominated by industrial agriculture. Tragedy, indeed: "If insects were to vanish, the environment would collapse into chaos" (Edward O. Wilson, the famous Harvard biologist dubbed the father of biodiversity; see Sverdrup-Thygeson, 2019). "The fates of humans and insects intertwine, especially through the medium of plants", write a group of 25 biologists in Samways et al. (2020, n.p.).

Consider, for instance, pollinators. Bees play a prominent, albeit far from exclusive, role in pollination. During the last 15 years, beekeepers have noticed a severe decline in bee populations - in particular, sudden implosions of entire colonies. During the last five years, decline turned to collapse in some key rural regions in the USA, in Europe and in Asia. The causes of the phenomenon have proved difficult to investigate scientifically. Two studies reported in Science (Stokstad, 2012) have significantly enhanced the credibility of the following explanation: while general factors like the impoverishment of the ecosystems in rural regions are highly detrimental to bees - factors that the industry blew up out of proportion - there are also specific factors, the effect of which better corresponds to the brutality of the phenomenon - factors that the industry strenuously minimized. The scientific results reported mainly point to the extensive use in industrial agriculture of pesticides, in particular a class of pesticides called neonicotinoids. These are not particularly toxic to mammals, a good argument to have them authorized by regulators, albeit an 
argument that neglects the concealed (at the time market access permission was sought) fact that they are highly toxic to all sorts of insects. Even when they are not directly lethal, they act on the nervous system of insects in ways that indirectly provoke individual and collective deaths: sublethal doses of neonicotinoids damage bees' memories, their ability to forage, and their ability to navigate back to their hives (Siviter et al., 2018); the production of queens is also drastically inhibited. And pesticides weaken the defenses against the damaging effects from the actions of fungi, parasites like mites, and viruses.

Damage is by no means confined to honeybees, as is convincingly shown in a broad review investigating a great number of species and places (Soroye, Newbold and Kerr, 2020). For bumble bees, the situation is made worse by their recently observed susceptibility to temperature increases (Sanchez Bayo and Wyckhuys, 2019). Without bumble bees the pollination of wildflowers will be seriously compromised. So much for Shakespeare's sonnets.

The situation is mind-boggling: pollinators act as mediators in ecosystems whose sustainability is dependent upon this very mediation. The economic values involved are vastly superior to the profits made from producing and selling the offending pesticides. Notwithstanding that neither market nor regulatory mechanisms came and corrected these "imbalances", an international regulation institution is nominally in charge but it is controlled by the pesticides oligopoly in ways that make the case a classic of regulatory capture and regulation impotence, as discussed in the next section.

Before proceeding to the next section, it is worth reminding ourselves of the deadliest deceit in the history of the US pharmaceutical industry. The mass marketing of powerful opioids as routine painkillers, with the complicity (generously compensated) of tens of thousands of MDs, as well as of the regulator (Food and Drug Administration), is a monument of deceit. Entrusted with keeping American people in as good health as possible, the pharmaceutical industry has in fact addicted millions to hard drugs and killed hundreds of thousands (McGreal, 2019). One might think that deceit on a large scale in matters of public health would not resurface for some years; it did in 2018, showing how ingrained it is in contemporary American capitalism.

In 2007, two graduate students in product design at Stanford University started a company called Ploom, with the objective of producing an e-cigarette that, in their own words, would be "a lot less dangerous to smokers and could be enjoyable". Released in 2010, the Ploom Model 1 Vaporizer, despite its attractive design, languished on the market; it didn't feel a really enjoyable experience.

During the second semester of 2017, Ploom, rebranded as Juul Labs, put on the market a product, simply called Juul, that almost immediately lifted its fortunes to stratospheric levels; by the end of 2018 Juul Labs was valued at $\$ 38$ billion, at the time overtaking Ford Motor Co. on Wall Street. The secret? 
An innovative e-cigarette feeling both powerful and smooth in nicotine, the perfect enjoyable hit that had been sought after for ten years, designed as the "iPhone" of e-cigarettes.

Juul's self-proclaimed mission was to provide adult regular smokers with a safe and attractive substitute to ordinary cigarettes. In fact, it mainly targeted, attracted and addicted non-smokers, in particular teenagers. Despite the legal prohibitions on the sale of e-cigarettes to minors, "juuling" quickly became a high-school craze, to the point of reversing a declining trend in youth use of nicotine products; over 25 percent of teenagers reported using Juul more than ten times a month, most of them unaware of the dangers they were facing. Lawsuits are currently piling in, from:

- parents of hundreds of thousands of children;

- school districts across the US, for misrepresenting the nicotine content of the products, marketing to children and endangering their health;

- counties and states, for systematic and widely successful campaigns to attract teenagers to e-cigarettes engineered to sustain addiction.

This indeed is capitalism for which the main engine of temporary financial successes is deceit.

\section{CAPITALISM OF INFLUENCE AND DOMINANCE}

Lobbying and pressurizing lawmakers, either at Congress in Washington, or across US state legislatures, is permanent and ubiquitous, bringing rich rewards to the corporations that hire the lobbyists. Here are two spectacular instances: driving the Texas legislature to vote in 2019 for the Texas Critical Infrastructure Protection Act, and, at federal level, politically killing a member of the House, for having introduced a carbon tax proposal, and using it as a warning to deter any legislative initiative in favor of the climate.

Oil and gas companies operating in Texas, BP, Chevron, ConocoPhillips, ExxonMobil, Shell and various fracking operators, have conspired with Texan lawmakers, the majority of whom are Republican and staunch climatoskeptics, to have a law passed that contains extraordinary measures aiming at hitting people or groups acting in defense of environment: if convinced of obstructing or damaging energy facilities, in particular pipelines, they would be liable to prison sentences of up to ten years and to fines of up to $\$ 500000$. Other Midwestern States have followed suit. For fossil-fuel companies and regional politicians, the rationale is simple and compelling: in order to have their interests protected, they want potential perturbators terrorized. The Trump administration is extending a helping hand, with an executive order giving dispensation to major projects, pipelines in particular, from environmental 
review. That will help the Keystone XL pipeline (XLK) being built despite all objections and oppositions. When built, XLK will bring heavy oil extracted from tar sands in the Canadian province of Alberta - extracting, refining and burning this stuff is even more damaging for the environment and the climate than processing and burning coal - to facilities along the Gulf of Mexico. Till recently, judicial decisions as well as actions by tens of thousands of protesters have made it impossible to start works on the ground. Then COVID-19 entered the picture and lockdowns kept protesters away. For the promoters of the project the opportunity was too good to be missed. During the last days of March 2020, ignoring lockdowns, they brought in workers from across the US, effectively taking advantage of the pandemics to advance their interests (McKibben, 2020). This industry tolerates no barrier against their interests; they refuse to recognize public interest, even at its most fundamental.

For the Koch brothers, Charles and David, owners of Koch Industries (circa $\$ 110$ billion of annual turnover in a variety of fossil-fuel businesses), fighting "climate change alarmism" and "moves to socialized healthcare" (they advocate scrapping Medicare and Medicaid) were priorities. When in 2009 Bob Inglis, Republican member for South Carolina of the House in Washington, proposed a bill introducing a carbon tax, the Kochs promoted a Tea Party activist against him, orchestrating and financing (as part of annual donations to the Tea Party that culminated at $\$ 17.5$ million in 2010) a ruthless campaign, that proved successful, as Inglis was not re-elected at the 2010 mid-term election. That sent a very explicit message to Republicans in Congress and contributed to the Obama administration's failure to have any meaningful climate bill passed. The Kochs were systematic in the defense of their businesses and ideological interests: they systematically lobbied undecided state legislatures in opposing measures supporting renewables (Leonard, 2019). The 2018 campaign to stop a carbon tax proposition in Washington State was conducted in the same spirit by a coalition of fossil-fuel companies. The proposition was voted down.

Apart from China - lobbying and bribing are common lubricants in dealings with and within the Chinese Communist Party - the US is the industrialized country where lobbying is most prevalent. However, others are not immune the EU for instance. Legal texts are being prepared at EU level for remedying pollution in rivers, lakes and wetlands, in order to bring them into "good ecological condition" by 2027. In order to derail the proposed legislation, lobbyists from the mining, chemical and agriculture sectors exercise maximum pressure on the Member States where firms in these sectors are particularly active; they have already enlisted the governments of Belgium, Germany and the Netherlands. A fierce battle is looming with the European Parliament, expected to oppose diluting the proposed legislation, and among governments of the Member States. It would seem that, on such an issue of clear public 
interest, there is no room for a battle; capitalism and its lobbyists think and act otherwise.

Several pesticides - atrazine, propisochlor, permethrin, and so on - have been banned from use in the EU since the beginning of the century; they had been proved too dangerous for both environment and public health. However, banned from use didn't imply banned from production feeding (highly profitable) sales in various African countries; the extent of the damage to public health and the environment is revealed at the Pesticide Politics in Africa conference (2019). A law passed by the French Parliament in October 2018 put an end to this "discrepancy", at least as far as France is concerned; it forbids producing, storing and transporting products banned from use in Europe. Since then the legislative and executive branches, up to the presidency, are targets of intense lobbying, meant to obstruct the implementation of the law. For the likes of Syngenta, Bayer, BASF, and so on, which produce the banned pesticides, Africans' well-being doesn't carry much weight. In financial terms, this is rational: highly hazardous pesticides, as they are called in the WHO-FAO nomenclature (WHO-FAO, 2018), make up more than half the total sales of pesticides in developing countries, and a third of the combined revenue, worldwide, of the five companies that dominate the market (these estimations are based on the data gathered by Phillips McDougall, crop science industry experts).

When agents from an industry penetrate an institution that is supposed to protect the environment and public health, to the point of occupying key executive or scientific positions within this institution, they are able to manipulate facts and rules in the interests of the industry. The nominations of two former fossil-fuel lobbyists, Andrew Wheeler, also former chief counsel to James Inhofe, the most outspoken climatoskeptic US Senator, as administrator - that is, head - of the Environmental Protection Agency; and of David Bernhardt, notorious in particular for having represented Wetlands Water District, in seeking to "un-do court-imposed protection for endangered salmon in Sacramento-San Joaquin delta", as US Secretary of the Interior (with authority on the no longer so well protected National Parks) are extreme cases, at least within democracies. However, they illuminate a trend in perversity resulting in "Death by a thousand cuts. It is not one issue, it's just across the board", according to historian Douglas Brinkley (Rice University, Austin, TX) - for example, weakening fuel-efficiency standards for new cars; ignoring mercury water pollution; lifting controls on methane emissions from flares and leaks in oil and gas production and transport; leasing protected public lands to fossil fuel companies; and sabotaging national and international efforts at reducing $\mathrm{CO}_{2}$ emissions. Another case comes from the sugar industry, as a broad scientific investigation has shown (Kearns, Glantz and Schmidt, 2015; Kearns, Schmidt and Glantz, 2016); it has contributed to make the US a world 
champion of obesity and diabetes (Moss, 2014). Building on their successes, lobbyists have expanded their networks into emerging economies where, according to Laura A. Schmidt, Professor of Health Policy at the School of Medicine, University of California at San Francisco, "the health infrastructure is less established and populations may be less informed about health hazards. If corporations can get in on the ground floor, they can shape the narratives and policies around unhealthy products" (cited in Jacobs, 2019). They can get in with disguised intermediaries, one of the most prominent ones being the International Life Sciences Institute. With about 400 affiliated corporations from the food and pharmaceutical industries, it is present in 17 countries and expanding. In India it has convinced the federal government to postpone sine die legislation requiring warning labels on processed foods with excessive fat, salt and sugar content (Jacobs, 2019). In China, sharing offices and staff with the Centers for Disease Control and Prevention, it succeeded in diverting prevention from dietary measures towards the promotion of physical activities, the positive effects of which are severely curtailed by the continuing predominance of unhealthy foods. In Brazil, the Institute has colonized the seats nominally reserved to academics in various committees or panels of experts (ibid.). These are examples of how firms dominating a vital sector of economic activity consolidate and expand their domination by infiltrating regulatory institutions.

In 1998, the European Parliament adopted a resolution calling upon the European Commission to tackle the problems raised by the proliferation of endocrine disruptors (EDs). Numerous synthetic chemicals - about 1000(?), it is impossible to know exactly as new chemicals are not adequately tested before being brought to the market - interfere with the hormonal system, disrupting production and transmission of hormones, as well as execution of messages received within the body, hence the name "endocrine disruptors" (Diamanti-Kandarakis, 2009; Mnif et al., 2011). It is no surprise that they have severe health effects, even causing damage to babies in the mother's womb. It took the Commission ten years to have a scientific report published (Kortenkamp et al., 2011). This report systematically assessed the dangers associated with the EDs and recommended appropriate regulatory control.

The concerned industry reacted swiftly, with guns pointed at the European Commission. The Commission was due to propose by December 2013 regulatory criteria informed by the Kortenkamp report. DG Env (Directorate General for the Environment) was in charge, and a broad meeting was convened at the Commission on June 7, 2013, to review the work in progress. It was disrupted by an email from Bayer Crop Sciences to the Commission General Secretariat, requiring an economic impact assessment before proceeding to regulation criteria; the economic impact would primarily be an evaluation of the impact on the activity of the industry. The meeting fell apart. Six years later there is 
still no regulatory framework in place. In the meantime, independent economic assessments have been provided: "EDC [endocrine-disrupting chemical] exposures in Europe contribute substantially to neurobehavioral deficits and diseases, with a high probability of $>€ 150$ billion costs/year" (Bellanger et al., 2015, p. 1256). The US corresponding figure, according to Attina (2016), is $\$ 340$ billion - that is, 2.3 percent of GDP. However, in the US, regulating EDs has not even been seriously contemplated.

\section{CONCLUSION}

In July 2007, when the financial subprime crisis was raging, Charles "Chunk" Prince, then CEO of Citigroup, famously uttered: "As long as the music is playing, you have got to get up and dance". Here also, as long as the familiar political, economic and financial music is playing, the fossil-fuel companies, the mining companies, the chemical "Konzerns", pharma firms, and so on, keep dancing. Dominant capitalism, under its various guises, cannot be stopped from destroying the essential natural capital our planet offers, and the conditions of almost all forms of life, ours in particular. It certainly cannot morph into a vehicle of the ecological and economic transition.

That doesn't imply that entrepreneurship has no future. It thrives in Costa Rica and Sweden, where entrepreneurs of all sizes play key roles in the transitions underway in these two pioneering countries (see Chapters 4 and 5 by respectively Monica Araya and Thomas Sterner in Part I: "Introduction"). In many other countries there also are entrepreneurs who work at driving transitions (see Part V: "Entrepreneurs" and also Henry and Tubiana, 2017). Nevertheless, on the unsustainable path on which dominant capitalism keeps accelerating, all worthwhile initiatives will be wiped away, as will the rest of us. We cannot survive under such dominant capitalism; it must be dismantled, or it is the planet- and life-support systems that will be dismantled (see the World Economic Forum's Global Risks Report 2020). Indeed, all components of natural capital - biodiversity, air, water, soil, climate - are currently crumbling, progressively leading to a condition of political, economic, social and moral decomposition, ultimately extending to Hannah Arendt's (1963) "banality of evil", worse than in today's Somalia or Venezuela. It is a matter of extreme urgency, for three main reasons:

- Ecological implosion is around the corner.

- Over the last four decades, inequalities have exploded all over the world (Atkinson, 2015, Piketty, 2014), even in Western Europe, albeit to a lesser extent than elsewhere; they make the immediate effects - not to mention the future ones - of climate change and other degradations of the natural 
capital definitely unbearable for those at the bottom, and the bottom is deep and thick.

- Capitalism is entering a phase when scientific and technological development produces overwhelming tools for manipulation, psychological and social anesthesia, surveillance and harassment, of the majority by an increasingly dominant minority.

"Somebody must do the job", remarked President John Kennedy. Who is available for the job here? Young people who fear for their future and older people who fear for their children and for their money. A fast-growing number of young people refuse the no-future fatality, hence refuse to go and work for companies that keep killing the future; they prefer to join those that are innovating for a sustainable future (see Part IV: "Coming Generations on the Front Line"). A fast-growing number of older people divest from the killers and invest in sustainability oriented businesses (see Part VI: "Investors"). Time has thus come for public authorities to confront the ultimate choice: go on cozying up to the deadly dancers or break the curse and lead on the way to survival.

\section{NOTES}

1. "A powerful system of lobbying and campaign finance is largely responsible for the growing monopolization of the US economy" (Philippon, 2019b).

2. In Qiu Xiaolong's novel Don't Cry Tai Lake, Chief Inspector Chen Cao clearly grasps what external effects can be:

Look at them. Paper mills, dyeing factories, chemical companies, and what not. In the last twenty years or so, those plants have sprung up like bamboo shoots after the rain. Sure, there's a city environmental office, but it exists only for appearance sake. Some of the factories are equipped with wastewater processing facilities, but they generally choose not to operate those facilities. The cost of doing so would wipe out their profits. So, they continue to dump waste into the lake in spite of the worsening crisis. (Qiu, 2012, p. 29)

By dumping waste, they consume valuable resources, for free: no economic mechanism, pricing, for instance, sanctions their actions. These actions are thefts of valuable resources, but environmental officers are zombies, hence there isn't any legal sanction either. The detrimental effects on the lake are external to both economic and legal mechanisms. Such external effects are ubiquitous, as Geoff Heal came to discover:

As many in my profession do, I first saw external effects as the exception rather than the rule, and as cute textbook examples rather than what they actually are: effects that rule the world, the norm rather than the exception. (Heal, 2017, p. 15)

3. Literally, "inferior people".

4. The Final Solution to the Jewish Question.

5. Meet oil sharks in Maddow (2019), Chapter 14, Igor Ivanovich Sechin and Rex Wayne Tillerson - that is, Rosneft and ExxonMobil - assaulting the Arctic Sea (see also Box 3.1 above).

6. Humans are not the sole victims of pandemics. For instance: amphibians are disappearing from the surface of the Earth, hit by the combined attacks of various pathogens and toxic fungi; after having killed more than 1 million olive trees 
in Southern Italy, bacterium Xylella fastidiosa is spreading to the other main Mediterranean olive oil-producing countries, a kind of "Terminator" that methodically devastates orchard after orchard.

7. That is, if vice hides behind hypocrisy, it's a nod to virtue.

8. "Voters believe that there is no consensus about global warming within the scientific community. Should the public come to believe that the scientific issues are settled, their views about global warming will change accordingly. Therefore, you need to continue to make the lack of scientific certainty a primary issue in the debate" (Burkeman, 2003).

\section{REFERENCES}

Akerlof, G. (1970), “The market for lemons: quality uncertainty and the market mechanism", Quarterly Journal of Economics, 84, 488-500.

Arendt, H. (1963), A Report on the Banality of Evil, New York: Viking Press.

Atkinson, A.B. (2015), Inequality - What Can Be Done?, Cambridge, MA: Harvard University Press.

Attina, T.M. (2016), "Exposure to endocrine-disrupting chemicals in the USA: a population-based disease burden and cost analysis", The Lancet: Diabetes and Endocrinology, 4 (12), 996-1003.

BankTrack, Rainforest Action Network and Sierra Club et al. (2019), Banking on Climate Change, Fossil Fuel Report Card 2019, accessed August 9, 2020 at https:// www.banktrack.org/download/banking_on_climate_change_2019_fossil_fuel finance_report_card/banking_on_climate_change_2019.pdf.

Be-llanger, $\bar{M}$., B. Demeneix and P. Grandjean et al. (2015), "Neurobehavioral deficits, diseases, and associated costs of exposure to endocrine disrupting chemicals in the European Union", The Journal of Clinical Endocrinology and Metabolism, 100, 1256-66.

Boykoff, B. and J. Boykoff (2004), "Balance as bias: global warming and the US prestige press", Global Environmental Change, 14, 125-36.

Burkeman, O. (2003), "Memo exposes Bush's green new strategy", The Guardian, March 4, accessed August 9, 2020 at https://www.theguardian.com/environment/ 2003/mar/04/usnews.climatechange.

Chabukdhara, M. (2016), "Coal mining in Northeast India: an overview of environmental issues and treatment approaches", International Journal of Coal Science and Technology, 3, 87-96.

Collins, E. (2019), Big Oil's Real Agenda on Climate Change, London: InfluenceMap. de la Rochefoucauld, F. (1664 [2012]), Maximes de la Rochefoucauld: Premier Texte Imprime à la Haye en 1664, Lexington, KY: Ulan Press.

Diamanti-Kandarakis, E., J.-P. Bourguignon and L.C. Giudice et al. (2009), "Endocrine-disrupting chemicals: an Endocrine Society scientific statement", Endocrine Reviews, 30 (4), 293-342.

Forests \& Finance (n.d.) [website], accessed August 26, 2020 at https://forestsandfinance .org/.

Global Development Policy Center (2020), "China's Global Energy Finance" [database], Boston University.

Heal, G.M. (2016), Endangered Economies: How the Neglect of Nature Threatens Our Prosperity, New York: Columbia University Press. 
Hefferman, O. (2019), "Seabed mining is coming - bringing mineral riches and fears of epic extinctions", Nature, 571 (7766), 465-68.

Henry, C. and L. Tubiana (2017), Earth at Risk: Natural Capital and the Quest for Sustainability, New York: Columbia University Press.

Hmiel, B., V.V. Petrenko and M.N. Dyonisius et al. (2020), "Preindustrial ${ }^{14} \mathrm{CH} 4$ indicates greater anthropogenic fossil $\mathrm{CH}_{4}$ emissions", Nature, 578 (7795), 409-12.

Hoggan, J. (2009), Climate Cover-up: The Crusade to Deny Global Warming, Vancouver: Greystone Books.

Howard, P., G. Parker and N. Jenner et al. (2020), An Assessment of the Risks and Impacts of Seabed Mining on Marine Ecosystems: Executive Summary, Cambridge, UK: Fauna \& Flora International.

Intergovernmental Panel on Climate Change (IPCC) (2018), Global Warming of $1.5^{\circ} \mathrm{C}$, Special Report, United Nations, October.

Intergovernmental Panel on Climate Change (IPCC) (2019), Climate Change and Land, Special Report, United Nations, August.

Intergovernmental Science-Policy Platform on Biodiversity and Ecosystem Services (IPBES) (2019), Global Assessment Report on Biodiversity and Ecosystem Services, United Nations, May.

Jacobs, A. (2019), "A shadowy industry group shapes food policy around the world", The New York Times, September 16, accessed August 10, 2020 at https://www .nytimes.com/2019/09/16/health/ilsi-food-policy-india-brazil-china.html.

Jouffray, J.-B., R. Blasiak and A.V. Norstrom et al. (2020), "The blue acceleration: the trajectory of human expansion into the ocean", One Earth, 2 (1), 43-54.

Kearns, C.E., S.A. Glantz and L.A. Schmidt (2015), "Sugar industry influence on the scientific agenda of the National Institute of Dental Research's National Caries Program: a historical analysis of internal documents", PLoS Medicine, 12 (3), e1001798.

Kearns, C.E., L.A. Schmidt and S.A. Glautz (2016), "Sugar industry and coronary heart disease research - a historical analysis of internal industry documents", JAMA Internal Medicine, 176 (11), 1680-85.

Kortenkamp, A., O. Martin and M. Faust et al. (2011), State of the Art Assessment of Endocrine Disruptors, Final Report to the European Commission, December 23.

Kreuder-Johnson, C., P.L. Hitchens and P.S. Pandit et al. (2020), "Global shifts in mammalian population trends reveal key predictors of virus spillover risk", Proceedings of the Royal Society B: Biological Sciences, 287 (1924), 201922736.

Leonard, C. (2019), Kochland: The Secret History of Koch Industries and Corporate Power in America, New York: Simon \& Schuster.

Maddow, R. (2019), Blowout: Corrupted Democracy, Rogue State Russia, and the Richest, Most Destructive Industry on Earth, New York: Crown/Penguin Random House.

McGreal, C. (2019), American Overdose - The Opioids Tragedy in Three Acts, New York: Public Affairs.

McKibben, B. (2020), "Big Oil is using the coronavirus pandemic to push through the Keystone XL pipeline", The Guardian, April 5.

Mnif, W., A. Hassine and A. Bouaziz et al. (2011), "Effects of endocrine disruptor pesticides: a review", International Journal of Environmental Resources and Public Health, 8, 2265-303.

Monbiot, G. (2019), "Shell is not a green saviour. It's a planetary death machine", The Guardian, June 26. 
Montgomery, C. (2006), "Mr. Cool: nurturing doubt about climate change is big business", Globe and Mail, Toronto, August 12, accessed August 9, 2020 at https:// web.archive.org/web/20110503192157/http://www.charlesmontgomery.ca/mrcool .html.

Moss, M. (2014), Salt, Sugar, Fat - How the Food Giants Hooked Us, New York: Random House.

Oreskes, N. and E. Conway (2010), Merchants of Doubt, New York: Bloomsbury Press.

Orwell, G. (1941), "Literature and totalitarianism", Listener [BBC radio broadcast], 21 May, accessed 9 August 2020 at https://www.orwell.ru/library/articles/ totalitarianism/english/e lat.

Pesticide Politics in Africa (2019), "The Arusha Call for Action on Pesticides Conference", Tropical Pesticides Research Institute, Arusha, Tanzania, May 31.

Picketty, T. (2014), Capital in the Twenty-First Century, Cambridge, MA: Harvard University Press.

Rainforest Action Network (2020), "Indonesia: on the frontlines of deforestation", in Keep Forests Standing: Exposing Brands and Banks Driving Deforestation (pp. 12-18), accessed August 26 at https://www.ran.org/wp-content/uploads/2020/ 03/RAN_Keep_Forests_Standing_vWEB.pdf.

Philippon, $\overline{\mathrm{T}}$. (2019a), The Great Reversal: How America Gave Up on Free Markets, Cambridge, MA: Belknap Press.

Philippon, T. (2019b), "Monopolies cost Americans \$300 a month. We are no longer the land of the free markets", The Guardian, November 13.

Qiu, X. (2012), Don't Cry, Tai Lake, New York: St. Martin's Press.

Redd Monitor (2019), "Shell boss says 'Another Brazil in terms of rainforest' is needed to address climate change. Meanwhile, Shell continues to profit from fossil fuels", accessed August 9, 2020 at https://redd-monitor.org/2019/03/22/shell -boss-says-another-brazil-in-terms-of-rainforest-needed-to-address-climate-change -meanwhile-shell-continues-to-profit-from-fossil-fuels/.

Samways, M.J., P.S. Barton, K. Birkhofer and F. Chichorro (2020), "Solutions for humanity on how to conserve insects", Biological Conservation, 242, 108427.

Sanchez-Bayo, F. and K. Wyckhuys (2019), "Worldwide decline of the entomofauna: a review of its drivers", Biological Conservation, 232, 8-27.

Securities and Exchange Commission (SEC) (n.d.), "Section 1504: Dodd Frank Wall Street Reform Act", accessed August 26, 2020 at https://www.sec.gov/comments/s7 -42-10/s74210-92.pdf.

Shell (2019), Energy for a Better Future: Annual Report and Accounts 2019, accessed August 9, 2020 at https://reports.shell.com/annual-report/2019/.

Siviter, H., J. Koricheva, M. Brown and E. Leadbeater (2018), "Quantifying the impact of pesticides on learning and memory in bees", Journal of Applied Ecology, 55 (6), $2812-21$.

Smith, A. (1776), An Inquiry into the Nature and Causes of the Wealth of Nations, London: W. Strahan and T. Cadell, in the Strand.

Soroye, P., T. Newbold and J. Kerr (2020), "Climate change contributes to widespread declines among bumble bees among continents", Science, 367, 685-8.

Souter, L.J., D. Herrera and D.J. Barrett et al. (2017), "Mining drives extensive deforestation in the Brazilian Amazon", Nature Communications, 8 (1), article 1013.

Steffen, W., J. Rockström and K. Richardson et al. (2018), "Trajectories of the Earth System in the Anthropocene", Proceedings of the National Academy of Science, 115 (33), 8252-9. 
Stern, N. (2007), "Climate change, ethics and the economics of the global deal", Royal Economic Society annual public lecture, University of Manchester, VoxEU.org, 30 November, accessed August 9, 2020 at https://voxeu.org/article/climate-change -ethics-and-economics.

Spencer, S. and K. Greenhalgh (2020), "Chevron ups Permian Basin resource estimate to over 21 billion boe, double 2017 estimate", S\&PGlobal.org, March 3, accessed August 9, 2020 at https://www.spglobal.com/platts/en/market-insights/latest-news/ natural-gas/030320-chevron-ups-permian-basin-resource-estimate-to-over-21-bil -boe-double-2017-estimate.

Stokstad, E. (2012), "Field research on bees raises concern about low-dose pesticides", Science, 335, 1555-6.

Sverdrup-Thygeson, A. (2019), Extraordinary Insects: Weird. Wonderful. Indispensable. The Ones Who Run Our World, London: Mudlark/HarperCollins.

Total (2020), "Suriname: Total and Apache make significant discovery in Block 58" [press release], January 7, accessed August 9, 2020 at https://www.total.com/media/ news/press-releases/suriname-total-and-apache-make-significant-discovery-block -58 .

Watson, R. (2019), "Biodiversity touches every aspect of our lives - so why has its loss been ignored?", The Guardian, September 19.

Watts, J. (2019), "Belt and Road Summit puts spotlight on Chinese coal funding", The Guardian, April 25.

World Economic Forum (WEF) (2020), The Global Risks Report 2020, accessed August 9, 2020 at http://www3.weforum.org/docs/WEF_Global_Risk_Report_2020 .pdf.

World Health Organization \& Food and Agriculture Organization of the United Nations (WHO-FAO) (2018), Global Situation of Pesticide Management in Agriculture and Public Health, annual report.

World Health Organization (WHO), United Nations Children's Fund (UNICEF) and The Lancet (2020), “A future for the world's children?", The Lancet Commissions, 395 (10224), 605-58.

Wilcox, B.A. and B. Ellis (2006), "Forests and emerging infectious diseases of humans", Unasylva, 57 (224), 11-18.

Wildlands League (2019), Boreal Logging Scars, December 4, accessed August 9, 2020 at https://wildlandsleague.org/media/LOGGING-SCARS-FINAL-Dec2019 -Exec-Summary.pdf. 